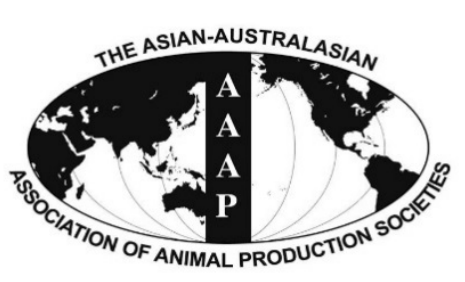

Open Access

Asian Australas. J. Anim. Sci.

Vol. 29, No. 11 : 1593-1600 November 2016

http://dx.doi.org/10.5713/ajas.15.0868

www.ajas.info

pISSN 1011-2367 elSSN 1976-5517

\title{
Effects of Starvation on Lipid Metabolism and Gluconeogenesis in Yak
}

\author{
Xiaoqiang Yu, Quanhui Peng, Xiaolin Luo ${ }^{1}$, Tianwu An¹, Jiuqiang Guan ${ }^{1}$, and Zhisheng Wang* \\ Animal Nutrition Institute, Key Laboratory of Low Carbon Culture and Safety Production in Cattle in Sichuan, \\ Sichuan Agricultural University, Ya'an, Sichuan 625014, China
}

\begin{abstract}
This research was conducted to investigate the physiological consequences of undernourished yak. Twelve Maiwa yak $(110.3 \pm 5.85 \mathrm{~kg})$ were randomly divided into two groups (baseline and starvation group). The yak of baseline group were slaughtered at day 0 , while the other group of yak were kept in shed without feed but allowed free access to water, salt and free movement for 9 days. Blood samples of the starvation group were collected on day $0,1,2,3,5,7,9$ and the starved yak were slaughtered after the final blood sample collection. The liver and muscle glycogen of the starvation group decreased $(p<0.01)$, and the lipid content also decreased while the content of moisture and ash increased $(\mathrm{p}<0.05)$ both in Longissimus dorsi and liver compared with the baseline group. The plasma insulin and glucose of the starved yak decreased at first and then kept stable but at a relatively lower level during the following days $(p<0.01)$. On the contrary, the non-esterified fatty acids was increased $(p<0.01)$. Beyond our expectation, the ketone bodies of $\beta$ hydroxybutyric acid and acetoacetic acid decreased with prolonged starvation $(p<0.01)$. Furthermore, the mRNA expression of lipogenetic enzyme fatty acid synthase and lipoprotein lipase in subcutaneous adipose tissue of starved yak were down-regulated $(\mathrm{p}<0.01)$, whereas the mRNA expression of lipolytic enzyme carnitine palmitoyltransferase- 1 and hormone sensitive lipase were upregulated $(\mathrm{p}<0.01)$ after 9 days of starvation. The phosphoenolpyruvate carboxykinase and pyruvate carboxylase, responsible for hepatic gluconeogenesis were up-regulated $(\mathrm{p}<0.01)$. It was concluded that yak derive energy by gluconeogenesis promotion and fat storage mobilization during starvation but without ketone body accumulation in the plasma. (Key Words: Starvation, Maiwa Yak, Fat Catabolism, Ketone Bodies, Gluconeogenesis)
\end{abstract}

\section{INTRODUCTION}

Yak (Bos grunniens) are the characteristic and important grazing livestock on the Qinghai-Tibetan Plateau. About 15 million or more than $90 \%$ of the world's total yak population are currently herded in Chinese territories, which are important for Tibetan herders in providing milk, meat and transport (Zhang et al., 2014). Yak have to survive during inadequate feed supply in the long cold season (October to May) due to herbage deficiency under traditional pure grazing farming system, which is a centuries old grassland yak production cycle, where the yak is expected to satiate in summer, fatten in fall, become thin

\footnotetext{
* Corresponding Author: Zhisheng Wang. Tel: +86-13308160896, Fax: +86-08352885730, E-mail: zswangsicau@126.com

1 Grassland Science Academy of Sichuan Province, Chengdu, Sichuan 611731, China.

Submitted Oct. 22, 2015; Revised Dec. 11, 2015; Accepted Feb. 29, 2016
}

in winter, and die in spring (Xue et al., 2005).

The biochemical profile of the livers of ruminant species shows striking differences from that of simplestomached animals. Therefore, it may not always be valid to extrapolate from the situation in rat liver to that in ruminant liver in order to interpret experimental observations in ruminants (Zammit, 1990). A large number of experiments had been done using sheep and goats (Piccione et al., 2002), young bulls (Tveit and Almlid, 1980), Angus cattle (Smith et al., 1998) to investigate the effects of starvation on circadian modulation and metabolism in adipose tissues. The most recent research declared that yak have developed special regulating mechanisms in the kidney in terms of glomerular filtration rate and purine derivative excretion to help the animal to adapt the alpine environment (Wang et al., 2009). Another paper from the same research team showed that the yak might be more efficient at utilizing $\mathrm{N}$ in a harsh environment than are cattle (Guo et al., 2012). 
However, there is no information on yak' fat storage mobilization and metabolism during starvation. Therefore, this experiment was conducted to investigate the fat mobilization and gluconeogenesis in the liver of yak during starvation.

\section{MATERIALS AND METHODS}

The experimental procedures used in this research were approved by the Institutional Animal Care of Sichuan Agricultural University.

\section{Site description}

This experiment was conducted at Guozhong Yak Breeding Farm, Hongyuan County, Sichuan Province, China $\left(101^{\circ} 51^{\prime}-103^{\circ} 23^{\prime} \mathrm{E}, 31^{\circ} 50^{\prime}-33^{\circ} 22^{\prime} \mathrm{N}\right)$, situated at the eastern edge of Qinghai-Tibetan Plateau. The altitude there was over $3,600 \mathrm{~m}$. The extreme minimum temperature was $-36^{\circ} \mathrm{C}$ during the experimental period (August, 2013).

\section{Experimental design and management}

Twelve healthy male Maiwa yak (3 yr old, body weight $110.3 \pm 5.85 \mathrm{~kg}$ ) were randomly divided into baseline and starvation groups, with 6 replicates in each group respectively. The animals were reared in a controlled indoor environment. In consideration of the gastric emptying time of ruminants being more than $120 \mathrm{~h}$, and previous experiment being conducted with steers (Pothoven and Beitz, 1975), the formal starvation experiment lasted 9 days. During this period, the animals were allowed free access to water and salt. The yak of baseline group were killed by electrical stunning coupled with exsanguination at 10:00 am on day 0 , whereas the starvation yak were killed with the same method on the 10th day morning.

\section{Sample collection and analysis}

Blood samples were taken from jugular vein into heparinized evacuated tubes on day $0,1,2,3,5,7,9$ at 0900 to $1000 \mathrm{~h}$, and centrifuged $(3,000 \mathrm{rpm})$ for $20 \mathrm{~min}$, plasma aliquots were frozen at $-20^{\circ} \mathrm{C}$ until the laboratory analysis. The concentration of plasma glucose, nonesterified fatty acids (NEFA), $\beta$-hydroxybutyric acid (BHBA) and acetoacetic acid (ACAC) were assayed using an automatic analyzer (Olympus AU 600, Diamond Diagnostics, Tokyo, Japan). The concentration of insulin was quantified using fluoroimmunoassay (AutoDELFIA; PerkinElmer Life and Analytical Sciences, Turku, Finland).

The liver and subcutaneous adipose tissues were cut into pieces and placed into $5 \mathrm{~mL}$ tubes and treated with liquid nitrogen immediately and transferred to $-80^{\circ} \mathrm{C}$ freezer for further analysis. Another $100 \mathrm{~g}$ of liver and Longissimus dorsi sample was collected and stored at $-20^{\circ} \mathrm{C}$ for proximate chemical composition analysis according to the Association of Official Analytical Chemists methods (AOAC, 1990).

\section{Primer design and real time-polymerase chain reaction analysis of gene expression}

The mRNA expression of pyruvate carboxylase (PC) and phosphoenolpyruvate carboxykinase (PEPCK) in the liver and fatty acid synthase (FAS), lipoprotein lipase (LPL), carnitine palmitoyltransferase-1 (CPT-1) and hormone sensitive lipase (HSL) in subcutaneous adipose tissue were detected by real time-polymerase chain reaction (PCR). Real time-PCR primers were designed using the software Beacon Designer 7.0 (Premier Biosoft International, Palo Alto, CA, USA) to avoid amplification of genomic DNA. The sequence of the primers used, the fragment size, annealing temperature and the sequence references of the expected PCR products are shown in Table 1. Total RNA

Table 1. Specific primers used for real-time quantitative polymerase chain reaction

\begin{tabular}{|c|c|c|c|c|}
\hline Genes & Accession No. & Primer sequence, $5^{\prime} \rightarrow 3^{\prime}$ & Length (bp) & Annealing $\mathrm{T}\left({ }^{\circ} \mathrm{C}\right)$ \\
\hline \multirow[t]{2}{*}{$\beta$-actin } & NM_173979 & CATCCGCAAGGACCTCTAC & 340 & 61.3 \\
\hline & & ATGCCAATCTCATCTCGTTTT & & \\
\hline \multirow[t]{2}{*}{ FAS } & NM_001012669 & ACCTCGTGAAGGCTGTGACTCA & 196 & 59.5 \\
\hline & & TGAGTCGAGGCCAAGGTCTGAA & & \\
\hline \multirow[t]{2}{*}{ LPL } & NM_001075120 & CTGGACGGTGACAGGAATGTAT & 131 & 59.4 \\
\hline & & CAGACACTGGATAATGCTGCTG & & \\
\hline \multirow[t]{2}{*}{ CPT-1 } & NM_001034349 & CAAAACCATGTTGTACAGCTTCCA & 111 & 58.4 \\
\hline & & GCTTCCTTCATCAGAGGCTTCA & & \\
\hline \multirow[t]{2}{*}{ HSL } & NM_001080220 & GATGAGAGGGTAATTGCCG & 100 & 62.0 \\
\hline & & GGATGGCAGGTGTGAACT & & \\
\hline \multirow[t]{2}{*}{ PEPCK } & AY145503.1 & GATGGAAAGTAGAGTGTGTGGGTG & 146 & 55.7 \\
\hline & & GATGGAAAGTAGAGTGTGTGGGTG & & \\
\hline \multirow[t]{2}{*}{$\mathrm{PC}$} & NM_177946.4 & TGCGGTCCATCCTGGTCAA & 87 & 63.3 \\
\hline & & ACGCCAGGTAGGACCAGTT & & \\
\hline
\end{tabular}

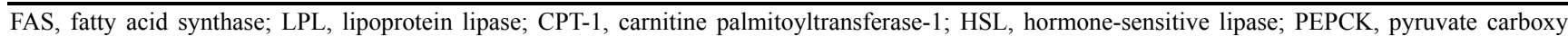
kinase; PC, pyruvate carboxylase. 
was isolated from samples using the Trizol reagent (TaKaRa, Dalian, China) following the manufacturer's instructions. The extracted RNA concentration was determined by a spectrophotometer at 260/280 $\mathrm{nm}$. Subsequently, a $2 \mu \mathrm{g}$ sample of total RNA was extracted for reverse transcription with DNase prior to reverse transcription to cDNA using a PrimeScript RT Reagent Kit (Takara, China), and it was performed with a Mastercycler (Eppendorf, Hamburg, Germany) at the following settings: $94^{\circ} \mathrm{C}$ for $2 \mathrm{~min}$, followed by 45 cycles of $94^{\circ} \mathrm{C}$ for $15 \mathrm{~s}$, specific annealing temperature for $30 \mathrm{~s}$, and $72^{\circ} \mathrm{C}$ for $30 \mathrm{~s}$. The expression changes of mRNA relative to housekeeping gene $\beta$-actin were validated by an SYBR-based High-Specificity miRNA qRT-PCR Detection Kit (TaKaRa, China) on the CFX96TM Real-Time PCR Detection System (Bio-Rad, Hercules, CA, USA). The volume of each PCR reaction was $20 \mu \mathrm{L}$. The $2^{-\Delta \Delta} \mathrm{Ct}$ method was used to determine the expression level differences between surveyed samples (Dorak, 2006).

\section{Statistical analysis}

A student T-test was carried out on the data of body weight, liver and Longissimus dorsi proximate chemical composition and gene expression. The MIXED model of SAS (SAS Institute, 1999) was used to analyze the data of insulin, glucose and ketones in the plasma, the model used was $\mathrm{Y}=\mu+\mathrm{T}_{\mathrm{i}}+\mathrm{e}_{\mathrm{ij}}$, where $\mathrm{Y}$ was the dependent variable, $\mu$ was the population mean for the variable; $T_{i}$ was the fixed effect of time points (time points $=7$ ), $\mathrm{e}_{\mathrm{ij}}$ was the random error associated with the observation ij. Tukey-Kramer procedure was applied to do the multiple comparisons. Means with different superscripts were obtained with "pdmix 800 SAS macro" (Saxton, 1998). Less than 0.05 p value was considered as statistically significant.

\section{RESULTS AND DISCUSSION}

\section{Body weight}

The effects of starvation on body weight of yak are shown in Table 2 . The body weight of the yak decreased by $9.84 \%$ after 9 days of starvation, and the carcass weight decreased by $9.71 \%$ compared with the baseline group $(\mathrm{p}<$ 0.05). Animals undergoing starvation decrease their metabolic rates and utilize stored energy such as glycogen, lipids and even protein to provide energy for survival, and weight loss is the most obvious and direct response (McCue,

Table 2. Effects of starvation on body weight of yak

\begin{tabular}{|c|c|c|c|c|}
\hline \multirow{2}{*}{ Item } & \multicolumn{2}{|c|}{ Treatment } & \multirow{2}{*}{ SEM } & \multirow{2}{*}{ p-value } \\
\hline & Baseline & Starvation & & \\
\hline Initial body weight $(\mathrm{kg})$ & 108.9 & 111.8 & 3.27 & 0.92 \\
\hline Final body weight (kg) & - & 100.8 & - & - \\
\hline Carcass weight (kg) & 51.5 & 46.5 & 3.66 & 0.05 \\
\hline
\end{tabular}

SEM, standard error of the mean.
2010). The body weight of yak decreased by only $9.84 \%$ after 9 days of starvation, while Kirton et al. (1972) reported that the beef cattle lost $10.2 \%$ of body weight after 4 days of pre-slaughter starvation. Chaiyabutr et al. (1980) reported that the body weight of lactating goats decreased by $16 \%$ after 2 days of starvation. This suggests that yak have a stronger tolerant capability for feed deficiency than other ruminants.

\section{Chemical composition of liver and muscle}

The effects of starvation on proximate chemical composition of muscle and liver are shown in Table 3. After 9 days of starvation, the moisture content increased by $1.47 \%$ and $2.65 \%$ in Longissimus dorsi and liver, respectively $(\mathrm{p}<0.01)$. Similarly, the ash content increased by $16.67 \%$ and $28.57 \%$ in Longissimus dorsi and liver, respectively $(\mathrm{p}<0.05)$. Conversely, the lipid content in Longissimus dorsi decreased by $58.33 \%$ and $2.50 \%$ $(\mathrm{p}<0.05)$. In addition, the protein content of Longissimus dorsi declined by $5.38 \%(\mathrm{p}<0.01)$, but increased by $5.88 \%$ in the liver $(\mathrm{p}<0.01)$. Under normal circumstances, along with the continuous consumption of energy, body moisture and ash content increases gradually. In present study, the moisture and ash content increased at the expense of lipid content both in muscle and liver, indicating the body fat storage was being utilized for energy supply. This was in agreement with Chwalibog et al. (2004), who reported that pigs started to mobilize body fat after approximately $16 \mathrm{~h}$ fasting. Furthermore, the protein content of Longissimus dorsi decreased, implying protein mobilization was also initiated. This was consistent with findings reported by Ndibualonji et al. (1997), who observed an increase of plasma 3-methylhistidine after 1 day of fasting in dairy cattle, which was the index of muscle protein catabolism. The fat storage was mobilized, and the total amount of liver lipid decreased by $8.0 \%$ as the consequence of the decrease

Table 3. Effect of starvation on liver and muscle proximate chemical composition of yak

\begin{tabular}{|c|c|c|c|c|}
\hline \multirow{2}{*}{ Item } & \multicolumn{2}{|c|}{ Treatment } & \multirow{2}{*}{ SEM } & \multirow{2}{*}{ p-value } \\
\hline & Baseline & Starvation & & \\
\hline \multicolumn{5}{|c|}{ Longissimus dorsi* } \\
\hline Moisture (\%) & 75.0 & 76.1 & 1.57 & $<0.01$ \\
\hline Protein (\%) & 22.3 & 21.1 & 0.63 & $<0.01$ \\
\hline Lipid (\%) & 1.2 & 0.5 & 0.17 & 0.01 \\
\hline Ash (\%) & 1.2 & 1.4 & 0.09 & 0.04 \\
\hline \multicolumn{5}{|l|}{ Liver } \\
\hline Moisture (\%) & 71.8 & 73.7 & 1.43 & $<0.01$ \\
\hline Protein (\%) & 17.0 & 18.0 & 0.57 & $<0.01$ \\
\hline Lipid (\%) & 4.0 & 3.9 & 0.11 & 0.04 \\
\hline Ash (\%) & 0.7 & 0.9 & 0.04 & 0.03 \\
\hline
\end{tabular}


of liver weight (Supplementary Table S1). This might mean to some extent the liver was no longer in a healthy state.

\section{Glycogen content in liver and muscle}

After 9 days of starvation, the liver glycogen decreased by $77.57 \%(\mathrm{p}<0.01)$, while the muscle glycogen decreased by $58.70 \% \quad(\mathrm{p}<0.01) \quad($ Table 4$)$. The amount of liver glycogen was obtained by glycogen concentration (Table 4) multiplied by liver weight (Supplementary Table S1). The amount of glycogen in the liver decreased by $79.16 \%$ $(\mathrm{p}<0.01)$. This was in line with former reports (Sugden et al., 1976; Meynial-Denis et al., 2005), which reported similar glycogen decrease of carcass and liver in rats. This, also indicated yak use liver glycogen first and subsequently the muscle glycogen. An unique phenomenon was documented indicating that starvation led to a depletion of liver glycogen during the first $48 \mathrm{~h}$ in golden hamsters. However, after 72 or $96 \mathrm{~h}$ of starvation a new glycogen accumulation was detected (Sasse, 1975). This implied that the gluconeogenesis function commenced when glycogen was exhausted.

\section{Plasma metabolites and insulin concentrations}

The effects of starvation on yak plasma insulin concentration are illustrated in Figure 1. Compared with day 0 , the insulin concentration decreased by $15.53 \%$ ( $<<$ $0.01)$, and further decreased by $47.13 \%(\mathrm{p}<0.01)$ after 2 days of starvation (Figure 1a). Compared with the data after 2 days of starvation, the insulin concentration increased by $26.88 \%$ after 3 days of starvation $(\mathrm{p}<0.01)$. Subsequently, the plasma insulin concentration kept stable, and no significant difference was observed $(\mathrm{p}>0.05)$. The plasma glucose decreased by $5.14 \%$ after 1 day of starvation ( $\mathrm{p}<$ $0.05)$, and continued to decrease by $22.67 \%(\mathrm{p}<0.01)$, compared with day 0 . During the following days, the glucose concentration kept relatively stable $(p>0.05)$ (Figure 1b). This was consistent with the trend of insulin. The trend of insulin and glucose in present study were also mirrored by the phenomenon observed in humans by Unger et al. (1963). These results suggested that yak could at least survive 9 days or even longer when feed was deprived with its plasma glucose kept stable though at a lower level.

The concentration of NEFA increased as the starvation period prolonged $(\mathrm{p}<0.01) \quad$ (Figure 1 $1 \mathrm{c})$. The NEFA concentration after 9 days of starvation increased by 4.60fold compared with day 0 . The increased NEFA after starvation was also observed in Holstein steers by DiMarco et al. (1981), with a slight difference, as about 8-fold of NEFA increase was obtained in the steers after 9 days of starvation. Brown Swiss steers had a 3.50-fold increase in NEFA after 8 days of starvation (Pothoven and Beitz, 1975). Reasons for the differences between different species warrant further investigations.
Table 4. Effect of starvation on liver and muscle glycogen of yak

\begin{tabular}{lcccc}
\hline \multirow{2}{*}{ Item } & \multicolumn{2}{c}{ Treatment } & \multirow{2}{*}{ SEM } & p-value \\
\cline { 2 - 3 } & Baseline & Starvation & & \\
\hline $\begin{array}{c}\text { Liver glycogen } \\
(\mu \mathrm{mol} / \mathrm{g} \text { tissue })\end{array}$ & 12.4 & 2.8 & 0.17 & 0.01 \\
$\begin{array}{c}\text { Muscle glycogen } \\
(\mu \mathrm{mol} / \mathrm{g} \text { tissue }) *\end{array}$ & 2.3 & 1.0 & 0.04 & 0.01 \\
\hline
\end{tabular}

SEM, standard error of the mean.

* Muscle was cut from Longissimus dorsi.

Usually, ketone bodies, BHBA, ACAC and acetone accumulate in the body fluids during starvation. Surprisingly, the concentration of BHBA in plasma decreased from day 0 to day 3 after starvation, then to a steady level till the end of the experiment $(p<0.01)$ (Figure 1d). As far as the ACAC was concerned, it decreased sharply from day 0 to day 3 after starvation $(p<0.01)$, and then decreased gradually till the end of the experiment $(\mathrm{p}<0.01)$ (Figure 1e). Under normal conditions, it is regarded that when hepatic glycogen originating from carbohydrate sources disappear, both ketones and free fatty acids serve to meet the physiologic requirement for energy. It was speculated that under circumstances of starvation ketosis, glucose provides about $10 \%$, ketone bodies about $32 \%$, and free fatty acids about $50 \%$ of the caloric needs in humans (Garber et al., 1974). On the other hand, in dairy cattle, determination of BHBA is considered as the golden standard to diagnose subclinical ketosis. The threshold concentration of BHBA to be regarded as subclinical ketosis is more than $1.2 \mathrm{mmol} / \mathrm{L}$ but less than $2.0 \mathrm{mmol} / \mathrm{L}$ (Iwersen et al., 2009; McArt et al., 2011). In addition, it was reviewed that the blood/plasma concentrations of BHBA (5 to $12 \mathrm{mmol} / \mathrm{L}$ ), ACAC ( 2 to $4 \mathrm{mmol} / \mathrm{L}$ ) and acetone ( 3 to 5 $\mathrm{mmol} / \mathrm{L}$ ) accumulated after several weeks of total fasting (Owen et al., 1983) in human. Our results demonstrated that BHBA concentration $(1.17 \mathrm{mmol} / \mathrm{L})$ was almost 40 -fold that of ACAC $(0.03 \mathrm{mmol} / \mathrm{L})$, and acetone was almost undetectable. Therefore, no acetone data was presented in this study. Acetone is mainly formed by spontaneous decarboxylation of ACAC. The relatively low concentration of ACAC and the undetectable acetone in plasma in present study indicating yak utilize ketone bodies more effective than other species. An unique ketone bodies metabolism mechanism may exist in the liver of yak. It might also be an advantage of yak against the harsh alpine environment gained through thousands of years evolution.

\section{Gene expression in subcutaneous adipose tissue and liver}

The effects of starvation on the key enzyme relative mRNA expression of fat metabolism and gluconeogenesis in subcutaneous adipose tissue and liver are shown in Figure 2a. The relative mRNA expression abundance of 
(a)

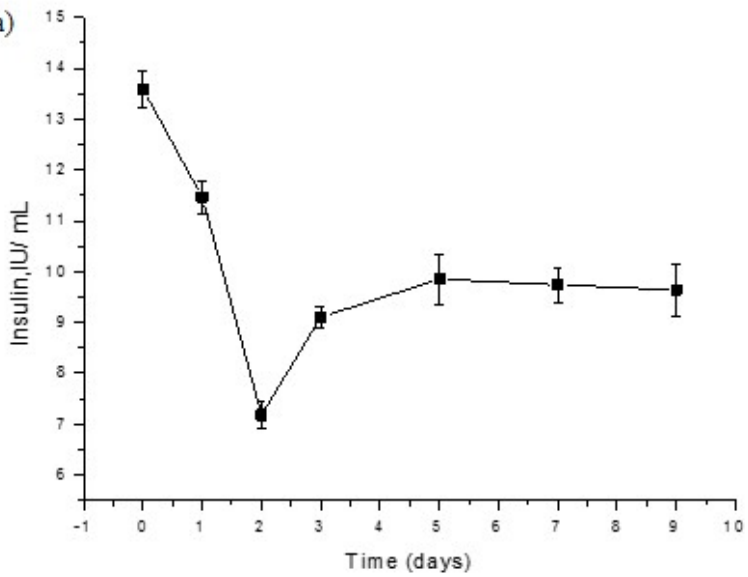

(c)

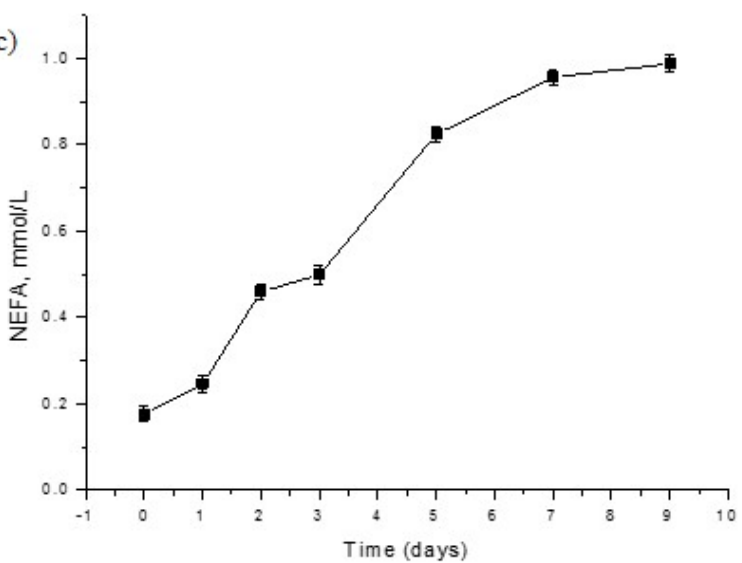

(e)

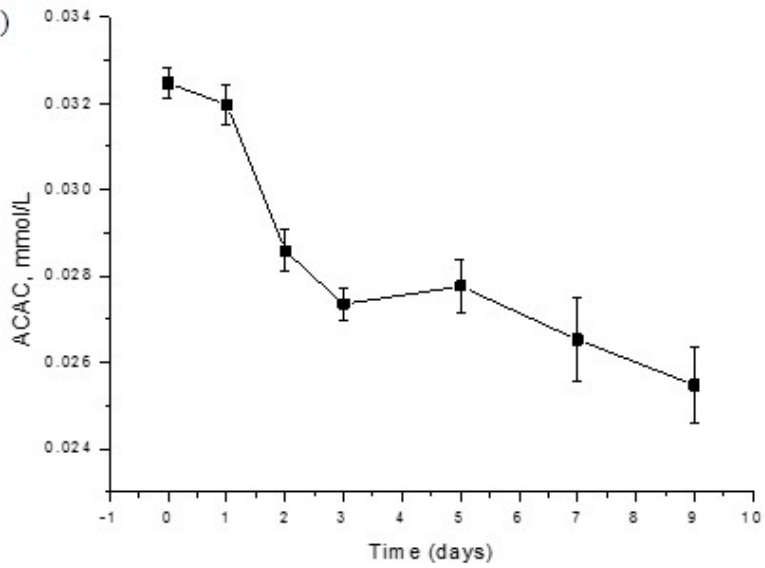

(b)

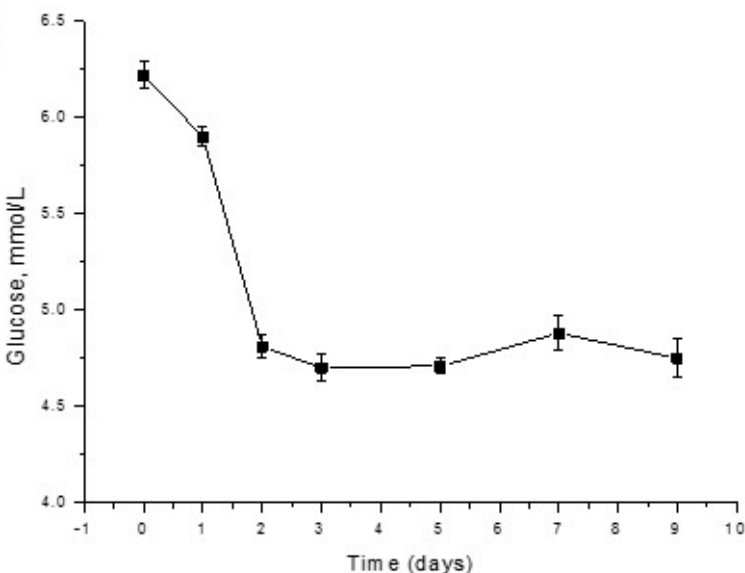

(d)

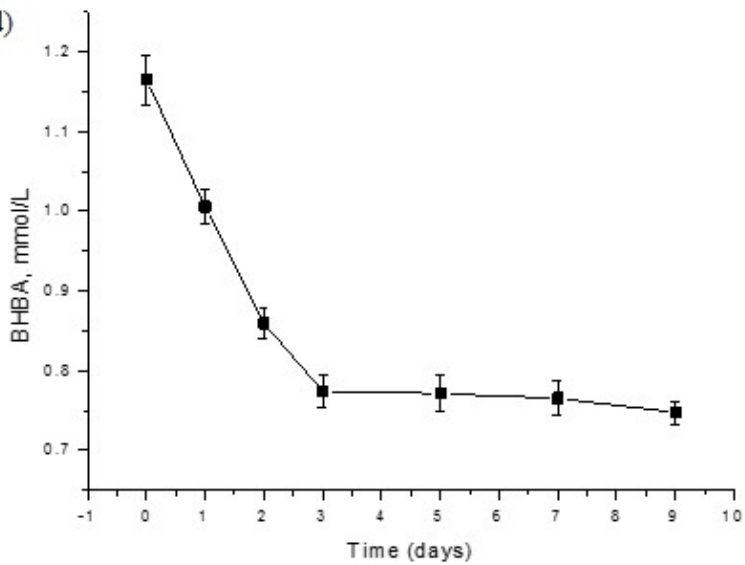

Figure 1. Effects of starvation on plasma insulin, glucose and ketone bodies concentration of yak. NEFA, non-esterified fatty acids; BHBA, $\beta$-hydroxybutyric acid; ACAC, acetoacetic acid. The vertical bars in figures are standard error of the mean.

lipogenic enzyme FAS and LPL in subcutaneous adipose tissue decreased by $86 \%$ and $83 \%(p<0.05)$, respectively. In the meanwhile, the expression abundance of lipolytic enzyme HSL and CPT-1 increased by 4.32 and 5.66-fold $(p<0.01)$, respectively. It was reported by Pothoven and Beitz (1975) that FAS of Brown Swiss steers decreased $60 \%$ in the backfat after 1 day of fasting and $99 \%$ after 8 days. The decrease of FAS in subcutaneous and epididymal fat in mice with prolonged starvation (within $24 \mathrm{~h}$ ) was also reported by Sponarova et al. (2005). These results indicated the lipolysis was accelerated while lipogenesis was inhibited. The decreased LPL mRNA expression abundance was supported by DiMarco et al. (1981), who reported 63\% decrease of LPL activity in subcutaneous adipose tissue in Holstein steers after 9 days of starvation. CPT- 1 is the ratelimiting enzyme for fatty acid oxidation, catalyzing the first step in the transport of long-chain fatty acids from the cytosol into the mitochondrial matrix (McGarry and Foster, 1980). The increase mRNA expression of CPT-1 observed in present study was in agreement with Loor et al. (2005), 

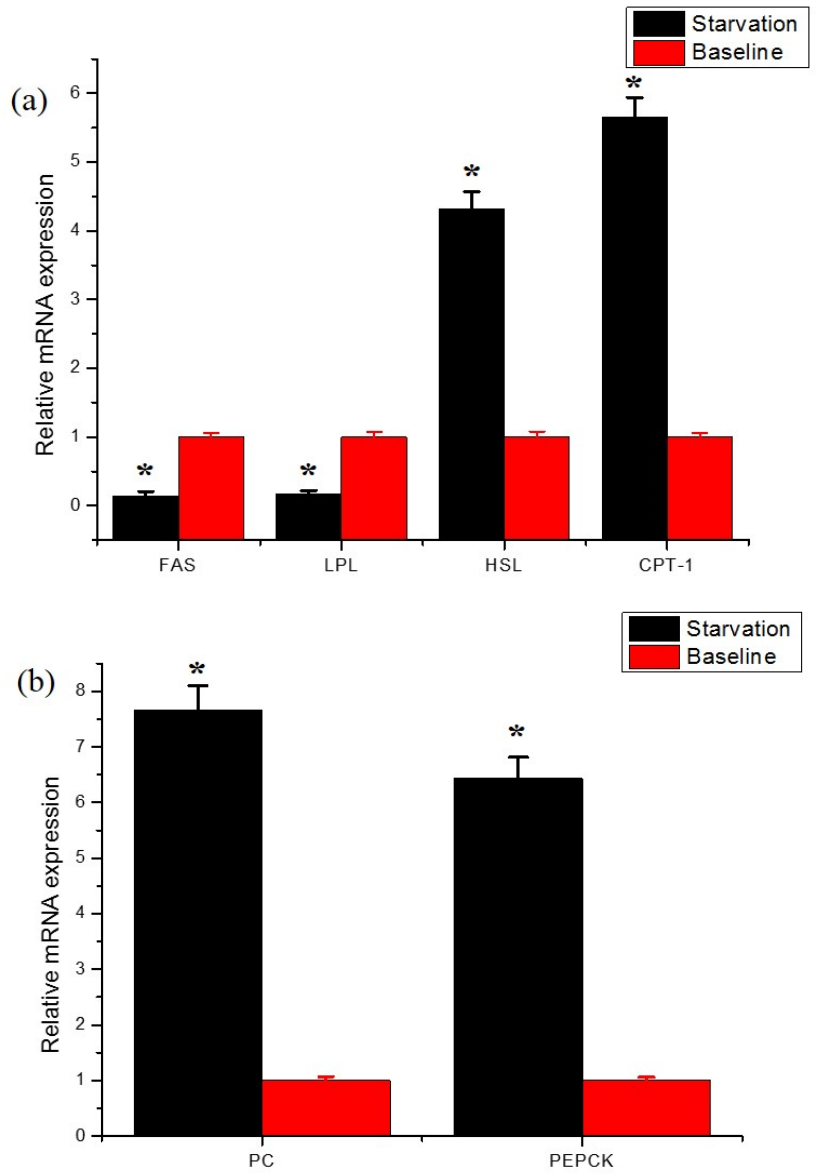

Figure 2. Relative abundance of mRNA expression of lipogenetic and lipolytic genes in subcutaneous adipose tissue and gluconeogenesis genes in the liver of yak. Values ( \pm standard error of the mean) are expressed as mRNA quantity relative to the baseline group, which was given a value of one. FAS, fatty acid synthase; LPL, lipoprotein lipase; CPT, carnitine palmitoyltransferase-1; HSL, hormone sensitive lipase; PEPCK, phosphoenol pyruvate carboxy kinase; PC, pyruvate carboxylase. The asterisk indicates that means significantly different at $p<0.01$ level.

who observed increased CPT mRNA expression in dairy cattle liver 1 day post-partum, when the animal was in the status of energy negative balance. Furthermore, the change trend of insulin and CPT-1 mRNA expression in present study was consistent with Li et al. (2013), who argued that high levels of insulin significantly inhibited the expression of genes related to fatty acid oxidation in calf hepatocytes. HSL is considered as a rate limiting enzyme in catabolism of fatty acids from intracellular triacylglycerol (Stralfors et al., 1987). Samra et al. (1996) studied the changes in lipid metabolism of adipose tissue in 24 healthy adults during early starvation (14 to $20 \mathrm{~h}$ ). They declared the increased transcapillary efflux of NEFA reflected a significant increase in the action rate of HSL. In addition, they also argued that insulin inhibits the activity of HSL. Both the NEFA and HSL mRNA expression increased while insulin decreased after starvation in present study. Bertile and Raclot (2011) also reported increased HSL mRNA expression and corresponding protein level $(\sim 1.3$ fold $)$ in fasted mice.

Genes that are important for hepatic adaptation are those encoding PEPCK and PC, which are described as ratelimiting enzymes for hepatic gluconeogenesis by Greenfield et al. (2000). They observed an increase in PC and PEPCK encoding mRNA abundance during the transition period when the dairy cattle are in negative energy balance condition. The mRNA expression of PC and PEPCK were increased 7.65 and 6.43 -fold after starvation in present study (Figure 2b). However, Velez and Donkin (2005) reported that mRNA expression of $\mathrm{PC}$ was increased during feed restriction $(50 \%$ of previously provided feed amount) and the capacity for gluconeogenesis from lactate was also increased while the mRNA expression of PEPKC was unchanged. This might indicate that different gluconeogenesis pathways are involved in different ruminants during starvation.

\section{CONCLUSION}

The liver and muscle glycogen of yak is almost exhausted and body fat storage is mobilized for energy supply after 9 days of starvation. On the other hand, the gluconeogenesis is up-regulated. These two aspects ensure the stability of blood glucose though at a relatvely lower level. During starvation, lipogenesis is depressed while the lipolysis is accelerated. This results in plasma non-esterified fatty acids accumulation. Unexpectedly, the ketone bodies BHBA and ACAC are decreased, whereas the actone is undetectable. This may be one of the physiological adaptations of yak after thousands of years selection to withstand the harsh alpine environment.

\section{CONFLICT OF INTEREST}

We certify that there is no conflict of interest with any financial organization regarding the material discussed in the manuscript.

\section{ACKNOWLEDGMENTS}

This work was supported by the National Natural Science Foundation of China (Grant No.31470121) and the special key technologies of converting grass efficiently to livestock in Qinghai-Tibetan plateau community (201203008).

\section{REFERENCES}

AOAC (Association of Official Analytical Chemists). 1990. 
Official Methods of Analysis, 15th edn. Association of Official Analytical Chemists, Arlington, VA, USA.

Bertile, F. and T. Raclot. 2011. ATGL and HSL are not coordinately regulated in response to fuel partitioning in fasted rats. J. Nutr. Biochem. 22:372-379.

Chaiyabutr, N., A. Faulkner, and M. Peaker. 1980. Effects of starvation on the cardiovascular system, water balance and milk secretion in lactating goats. Res. Vet. Sci. 28:291-295.

Chwalibog, A., A. H. Tauson, and G. Thorbek. 2004. Diurnal rhythm in heat production and oxidation of carbohydrate and fat in pigs during feeding, starvation and re-feeding. J. Anim. Physiol. Anim. Nutr. 88:266-274.

DiMarco, N. M., D. C. Beitz, and G. B. Whitehurst. 1981. Effect of fasting on free fatty acid, glycerol and cholesterol concentrations in blood plasma and lipoprotein lipase activity in adipose tissue of cattle. J. Anim. Sci. 52:75-82.

Dorak, M. T. 2006. Real-Time PCR, 1st edn, Taylor\& Francis Group, New York, USA.

Garber, A. J., P. H. Menzel, G. Boden, and O. E. Owen. 1974. Hepatic ketogenesis and gluconeogenesis in humans. J. Clin. Invest. 54:981-989.

Greenfield, R. B., M. J. Cecava, and S. S. Donkin. 2000. Changes in mRNA expression for gluconeogenic enzymes in liver of dairy cattle during the transition to lactation. J. Dairy Sci. 83:1228-1236.

Guo, X. S., Y. Zhang, J. W. Zhou, R. J. Long, G. S. Xin, B. Qi, L. M. Ding, and H. C. Wang. 2012. Nitrogen metabolism and recycling in yaks (Bos grunniens) offered a forage-concentrate diet differing in N concentration. Anim. Prod. Sci. 52:287-296.

Iwersen, M., U. Falkenberg, R. Voigtsberger, D. Forderung, and W. Heuwieser. 2009. Evaluation of an electronic cowside test to detect subclinical ketosis in dairy cows. J. Dairy Sci. 92:26182624.

Kirton, A. H., D. J. Paterson, and D. M. Duganzich. 1972. Effect of pre-slaughter starvation in cattle. J. Anim. Sci. 34:555-559.

Li, P., C. C. Wu, M. Long, Y. Zhang, X. B. Li, J. B. He, Z. Wang, and G. W. Liu. 2013. Short communication: High insulin concentrations inhibit fatty acid oxidation-related gene expression in calf hepatocytes cultured in vitro. J. Dairy Sci. 96:3840-3844.

Loor, J. J., H. M. Dann, R. E. Everts, R. Oliveira, C. A. Green, N. A. J. Guretzky, S. L. Rodriguez-Zas, H. A. Lewin, and J. K. Drackley. 2005. Temporal gene expression profiling of liver from periparturient dairy cows reveals complex adaptive mechanisms in hepatic function. Physiol. Genomics 23:217226.

McArt, J. A. A., D. V. Nydam, P. A. Ospina, and G. R. Oetzel. 2011. A field trial on the effect of propylene glycol on milk yield and resolution of ketosis in fresh cows diagnosed with subclinical ketosis. J. Dairy Sci. 94:6011-6020.

McCue, M. D. 2010. Starvation physiology: Reviewing the different strategies animals use to survive a common challenge. Comp. Biochem. Physiol. Part A Mol. Integr. Physiol. 156:118.

Meynial-Denis, D., A. Miri, G. Bielicki, M. Mignon, J. P. Renou, and J. Grizard. 2005. Insulin-dependent glycogen synthesis is delayed in onset in the skeletal muscle of food-deprived aged rats. J. Nutr. Biochem. 16:150-154.
McGarry, J. and D. Foster. 1980. Regulation of hepatic fatty acid oxidation and ketone body production. Annu. Rev. Biochem. 49:395-420.

Ndibualonji, B. B., D. Dehareng, and J. M. Godeau. 1997. Effects of starvation on plasma amino acids, urea and glucose in dairy cows. Ann. Zootech. 42:163-174.

Owen, O. E., S. Caprio, G. A. Reichard, M. A. Mozzoli, G. Boden, and R. S. Owen. 1983. 6 ketosis of starvation: A revisit and new perspectives. Clin. Endocrinol. Metab. 12:359-379.

Piccione, G., G. Caola, and R. Refinetti. 2002. Circadian modulation of starvation-induced hypothermia in sheep and goats. Chronobiol. Int. 19:531-541.

Pothoven, M. A. and A. C. Beitz. 1975. Changes in fatty acid synthesis and lipogenic enzymes in adipose tissue from fasted and fasted-refed steers. J. Nutr. 105:1055-1061.

SAS (Statistical Analysis System) Institute. 1999. User's Guide: Statistics. 8th edn. SAS Institute Inc., Cary, NC, USA.

Sasse, D. 1975. Dynamics of liver glycogen. Histochemistry 45:237-254.

Samra, J. S., M. L. Clark, S. M. Humphreys, I. A. Macdonald, and K. N. Frayn. 1996. Regulation of lipid metabolism in adipose tissue during early starvation. Am. J. Physiol. Endocrinol. Metab. 271:E541-E546.

Saxton, A. M. 1998. A macro for converting mean separation output to letter groupings in proc mixed. In: Proceedings of the 23rd SAS Users Group International. SAS Institute, Cary, NC. pp. 1243-1246.

Smith, S. B., K. C. Lin, J. J. Wilson, D. K. Lunt, and H. R. Cross. 1998. Starvation depresses acylglycerol biosynthesis in bovine subcutaneous but not intramuscular adipose tissue homogenates. Comp. Biochem. Physiol. Part B Biochem. Mol. Biol. 120:165-174.

Sponarova, J., K. J. Mustard, O. Horakova, P. Flachs, M. Rossmeisl, P. Brauner, K. Bardova, M. Thomason-Hughes, R. Braunerova, and P. Janovska et al. 2005. Involvement of AMPactivated protein kinase in fat depot-specific metabolic changes during starvation. FEBS. Lett. 579:6105-6110.

Stralfors, P., H. Olsson, and P. Belfrage. 1987. Hormone-sensitive lipase. Enzymes18:147-177.

Sugden, M. C., S. C. Sharples, and P. J. Randle. 1976. Carcass glycogen as a potential source of glucose during short-term starvation. Biochem. J. 160: 817-819.

Tveit, B. and T. Almlid. 1980. T4 degradation rate and plasma levels of TSH and thyroid hormones in ten young bulls during feeding conditions and $48 \mathrm{~h}$ of starvation. Acta Endocrinol. 93:435-439.

Unger, R. H., A. M. Eisentraut, and L. L. Madison. 1963. The effects of total starvation upon the levels of circulating glucagon and insulin in man. J. Clin. Invest. 42:1031-1039.

Velez, J. C. and S. S. Donkin. 2005. Feed restriction induces pyruvate carboxylase but not phosphoenolpyruvate carboxykinase in dairy cows. J. Dairy Sci. 88:2938-2948.

Wang, H., R. Long, W. Zhou, X. Li, J. Zhou, and X. Guo. 2009. A comparative study on urinary purine derivative excretion of yak (Bos grunniens), cattle (Bos taurus), and crossbred (Bos taurus $\times$ Bos grunniens) in the Qinghai-Tibetan plateau, China. J. Anim. Sci. 87:2355-2362.

Xue, B., X. Q. Zhao, and Y. S. Zhang. 2005. Seasonal changes in weight and body composition of yak grazing on alpine- 
meadow grassland in the Qinghai-Tibetan plateau of China. J. Zhang, H. B., Z. S. Wang, Q. H. Peng, C. Tan, and H. W. Zou. Anim. Sci. 83:1908-1913.

Zammit, V. A. 1990. Ketogenesis in the liver of ruminantsadaptations to a challenge. J. Agric. Sci. 115:155-162. 2014. Effects of different levels of protein supplementary diet on gene expressions related to intramuscular deposition in early-weaned yaks. Anim. Sci. J. 85:411-419. 